\title{
Numerical Study of The Airfoil Pitch Angle on The Darrieus-Savonius Combination Turbine
}

\author{
Erifive Pranatal ${ }^{1}$, Renanda Bayu Harsi ${ }^{2}$ \\ ${ }^{1}$ Lecturer, Department Naval Architecture, Adhi Tama Institute of Technology, Surabaya \\ ${ }^{2}$ Student, Department Naval Architecture, Adhi Tama Institute of Technology, Surabaya \\ Email: 1erifive@itats.ac.id, ${ }^{2}$ renanda.harsi27@gmail.com
}

\begin{abstract}
Turbin Darrieus banyak digunakan sebagai konverter arus laut untuk menghasilkan energi listrik terbarukan. Salah satu cara untuk meningkatkan performa turbin adalah dengan mencari sudut pitch optimal. Oleh karena itu tujuan penelitian ini adalah menentukan sudut optimal sudut pitch dari airfoil NACA 0018 dengan variasi sudut $-6^{\circ},-2^{\circ}, 0^{\circ}$ dan $2^{\circ}$. Metode Numerik dengan bantuan software Ansys Fluent dilakuan untuk mengevaluasi turbin tersebut. Hasil penelitian adalah sudut $2^{\circ}$ menghasilkan koefisin daya dan torsi terbesar dibandingakan sudut yang lain. Hal ini terjadi karena arah gaya angkat pada airfoil kedepan sesuai dengan perputaran turbin.
\end{abstract}

Keywords: Arus laut, Turbin, sudut pitch

\begin{abstract}
The Darrieus turbine is used as an ocean current converter to generate renewable electrical energy. One way to improve turbine performance is to determine the optimal pitch angle. Therefore, the purpose of this study was to determine the optimal pitch angle of the NACA 0018 airfoil with angle variations of $-6^{\circ},-2^{\circ}, 0^{\circ}$ and $2^{\circ}$. Numerical method with the help of Ansy Fluent software was carried out for the construction of the turbine. The result of this research is that the angle of $2^{\circ}$ produces the largest coefficient of power and torque compared to other angles. This happens because the direction of the lifting force on the forward airfoil is in accordance with the rotation of the turbine.
\end{abstract}

Keywords: Ocean Current, Turbine, Pitch Angle

\section{Introduction}

Renewable energy is starting to be widely used in everyday life. This happens because of the awareness of the dangers of using fossil energy that can cause global warming so that there will be a future climate crisis. One of the renewable energy is ocean currents. This energy is available and will never run out. In some places there are ocean currents that can be used to generate electricity. The tool to convert energy from ocean currents into electrical energy is a turbine. Ocean currents turn a turbine, where the turbine drives a dynamo to produce electrical energy.

In this study, the turbine used is a vertical axis turbine and a combination of the Darrieus turbine and the Savonius turbine which has been studied previously [1]. Turbine optimization is carried out to produce greater torque and power than the previous design. One of the methods used is the optimization of the pitch angle of the Darrieus turbine blades. Similar research has been carried out, namely discussing the effect of the Darrieus turbine angle of attack on the lift and drag forces [2]. In this study, the effect of changing the pitch angle on the torque and power coefficient is studied. So that the angle that produces good torque or power is obtained. The pitch angle variations selected are $6^{\circ},-2^{\circ}, 0^{\circ}$, and $2^{\circ}$.

The same research has been carried out on vertical axis turbine, combination of Darrieus and Savonius: M. Abid et. al [3] perfected the Darrieus turbine which was not effective in self starting by combining it with Savonius. The design of this combination turbine can be seen in Figure 1 . Experimental tests at wind speeds of $3 \mathrm{~m} / \mathrm{s}$ to $20 \mathrm{~m} / \mathrm{s}$, yielded an average power of 50 watts. Kaprawi 
Sahim et. al [4] performed a combination of Darrieus and Savonius turbines with and without a deflector. The turbine design can be seen in Figure 2

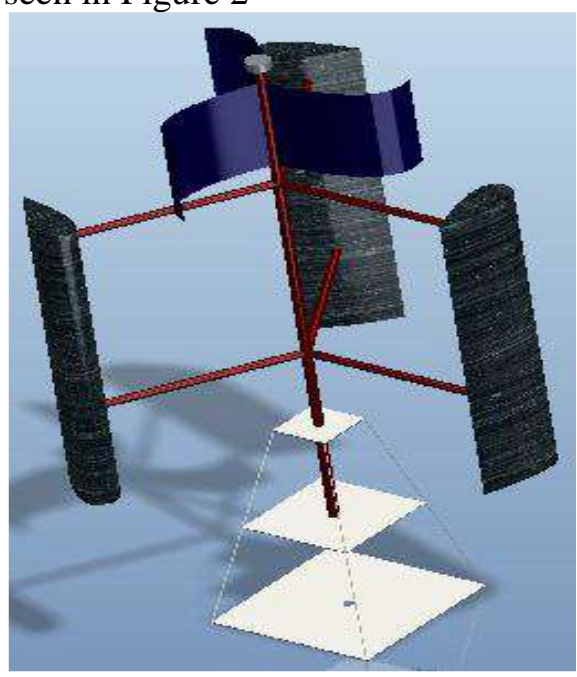

Figure 1. D-S Combination Turbine [3]

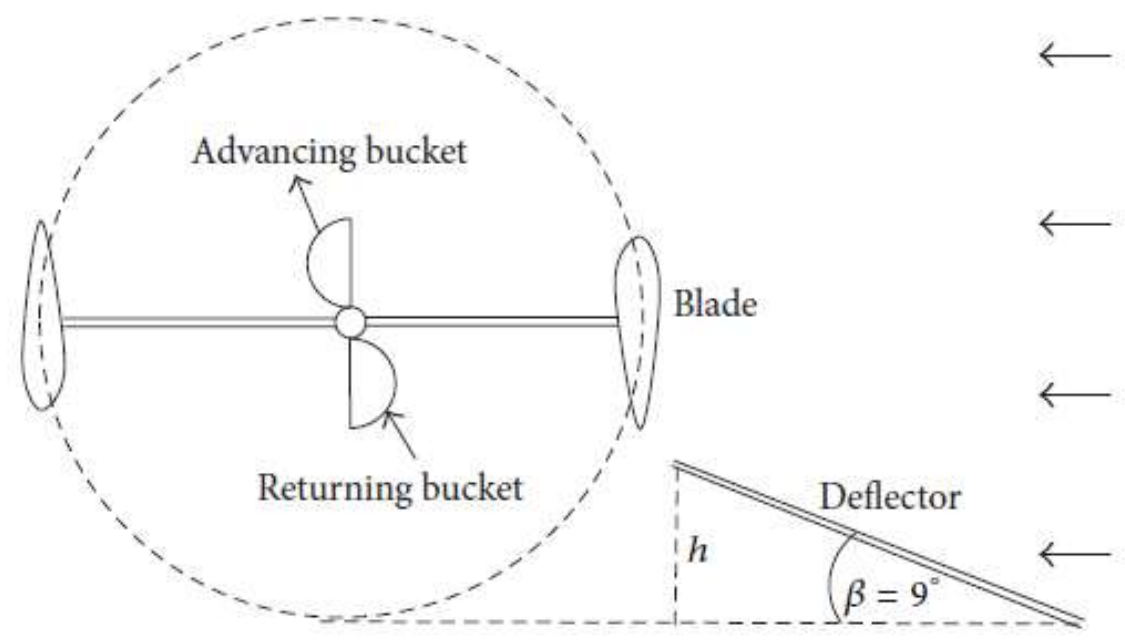

Figure 2. D-S Combination Turbine [4]

Research on the Darrieus turbine was carried out by Iwan Kurniawan [5] where the previously straight turbine blades were converted into a helix shape with variations in angles of $60^{\circ}$ and $120^{\circ}$. The design of the turbine can be seen in Figure 3. 

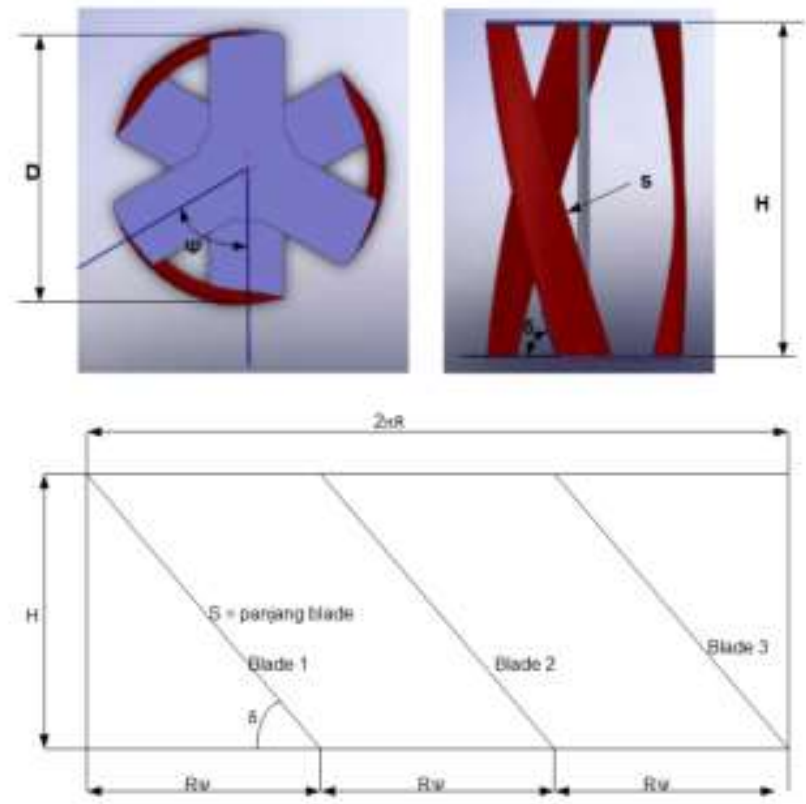

Figure 3. Darrieus Turbine Helix Blade [6]

Meanwhile, in this study, variations in pitch angle on the D-S combination turbine were carried out. Turbine model can be seen in Figure 4.

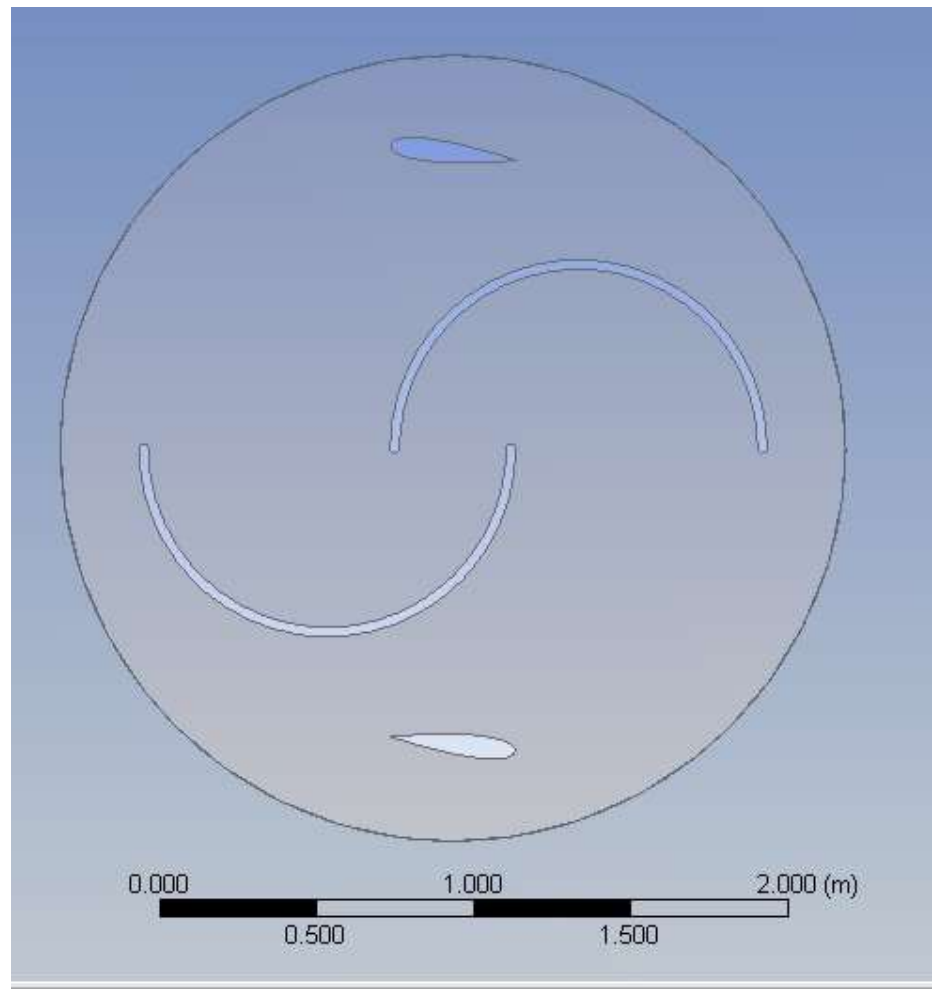

Figure 4. D-S Combination Turbine 


\section{Method}

The flow of research completion can be seen in Figure 4:

The method used for this research is a numerical method with the help of Ansys Fluent software with 2D analysis.

\subsection{Turbine Model}

The turbine model can be seen in Figure 3 and the turbine size is in Table 1 below:

Table 1. Turbine Sizes

\begin{tabular}{crrr}
\hline Item & Satuan & \multicolumn{2}{c}{ Unit } \\
\hline Turbine Diameter & $\mathrm{m}$ & 2 \\
Paddle Diameter & $\mathrm{m}$ & 0.8 \\
Cord Length & $\mathrm{m}$ & 0.4 \\
\hline
\end{tabular}

The paddle diameter is the diameter of the Savonius type turbine which is semi-circular. The paddle in Figure 4 is of the overlap type, with an overlap value of $0.4 \mathrm{~m}$. The type of airfoil used is NACA 0018 which can be seen in Figure 5 below:

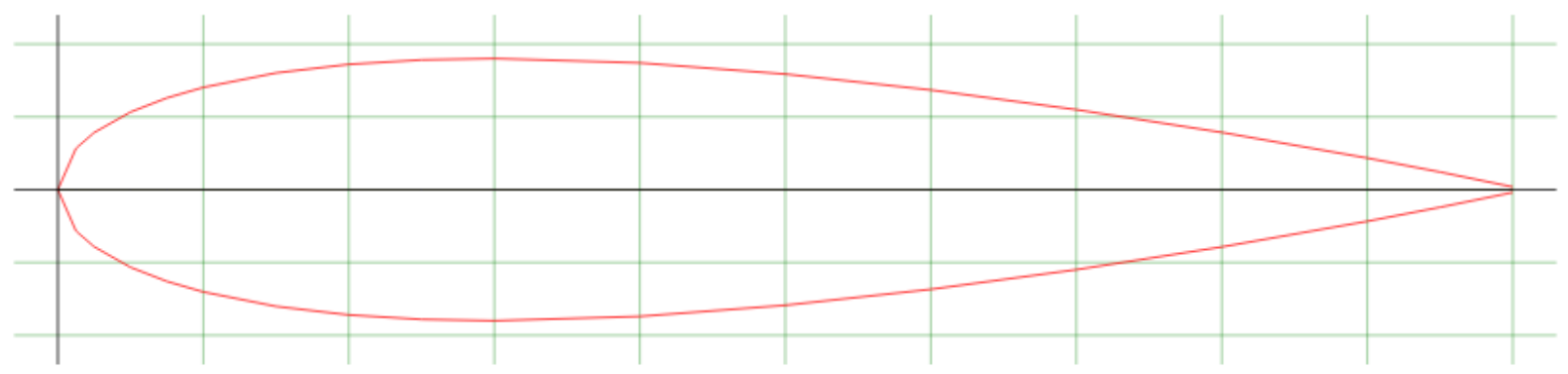

Figure 5. NACA Profile 0018

The model is made in four variations of angles, namely $-6^{\circ},-2^{\circ}, 0^{\circ}$ and $2^{\circ}$. Next, we will do a mesh and determine the limits of numerical simulation.

\subsection{Numerical Simulation}

The Meshing used is triangles. The number of mesh in this simulation is 447,100 and 262,336 nodes. Numerical model and solver details can be seen in Table 2 below:

Table 2. Numerical model and detail solver

\begin{tabular}{ccc}
\hline No & Solution Type & Sliding Mesh \\
\hline 1 & Transient & 2nd order implicit \\
\hline 2 & Turbulence & k- $\omega$ based SST \\
\hline 3 & Pressure & 2nd order \\
\hline 4 & Momentum & 2nd order \\
\hline 5 & $\omega$ & 2nd order \\
\hline 6 & $\mathrm{k}$ & 2nd order \\
\hline 7 & P-V Coupling & Pressure based non segregated \\
\hline
\end{tabular}

Numerical simulation results will produce some necessary data such as power and torque produced by the turbine at a predetermined speed. These results will be used in the following Formulas 1, 2 and 3 to determine the performance of the turbine [6]: 


$$
\begin{aligned}
& C m=\frac{T}{1 / 4 \rho A D U^{2}} \\
& C p=\frac{P}{1 / 2 \rho A U^{3}} \\
& T S R=\frac{\omega D}{2 U}
\end{aligned}
$$

2.3. Analysis of Numerical Simulation Results

The analysis was carried out on the simulation results from the variation of angles in the form of tables and graphs. And conclusions are drawn from these results.

\section{Results and Discussion}

The simulation results for turbines with variations in pitch angle can be seen in Table 2, Table 3, Figures 6 and 7.

Table 2. Torque Coefficient At Variation Of Pitch Angle

\begin{tabular}{crrrr}
\hline TSP & \multicolumn{4}{c}{$C t$} \\
\hline & $\mathbf{- 6}^{\circ}$ & $\mathbf{- 2}^{\circ}$ & $\mathbf{0}^{\circ}$ & $\mathbf{2}^{\circ}$ \\
\hline $\mathbf{0 . 8}$ & 0.093 & 0.113 & 0.125 & 0.132 \\
\hline $\mathbf{1 . 2}$ & 0.097 & 0.098 & 0.135 & 0.142 \\
\hline $\mathbf{1 . 6}$ & 0.070 & 0.069 & 0.090 & 0.102 \\
\hline $\mathbf{2}$ & -0.051 & -0.009 & -0.050 & -0.042 \\
\hline
\end{tabular}

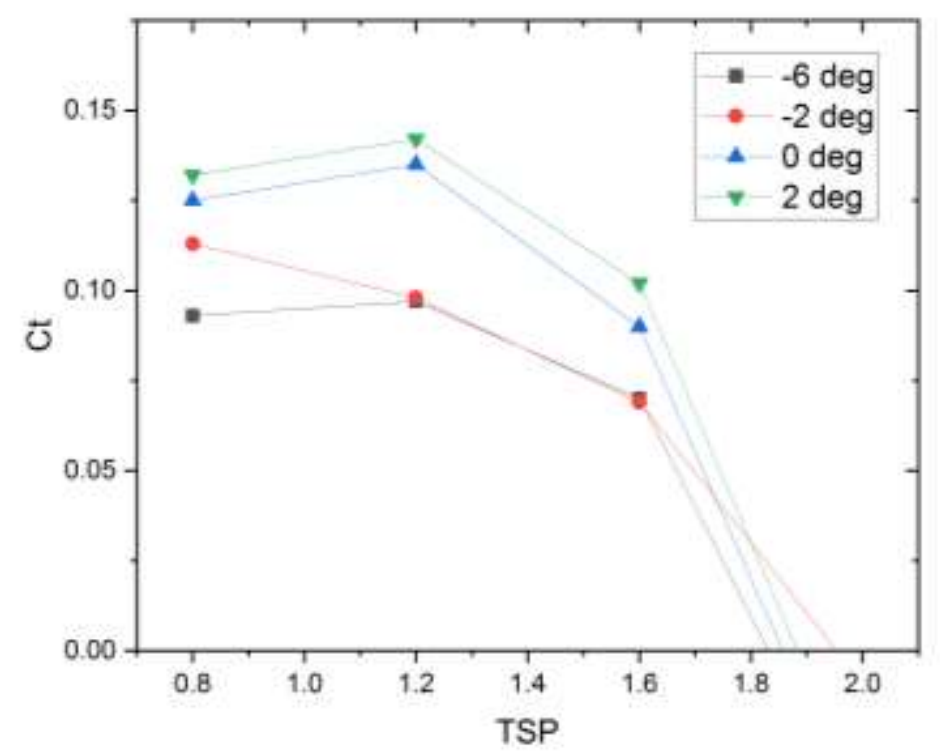

Figure 6. TSP versus CT Chart with Pitch Angle Variation 
Table 3. Power Coefficient At Variation Of Pitch Angle

\begin{tabular}{crrrr}
\hline TSP & \multicolumn{4}{c}{$C t$} \\
\hline & $\mathbf{- 6}^{\circ}$ & $\mathbf{- 2}^{\circ}$ & $\mathbf{0}^{\circ}$ & $\mathbf{2}^{\circ}$ \\
\hline $\mathbf{0 . 8}$ & 0.075 & 0.090 & 0.0996 & 0.1054 \\
\hline $\mathbf{1 . 2}$ & 0.116 & 0.117 & 0.1624 & 0.1701 \\
\hline $\mathbf{1 . 6}$ & 0.111 & 0.110 & 0.1443 & 0.1631 \\
\hline $\mathbf{2}$ & -0.103 & -0.017 & -0.0995 & -0.0845 \\
\hline
\end{tabular}

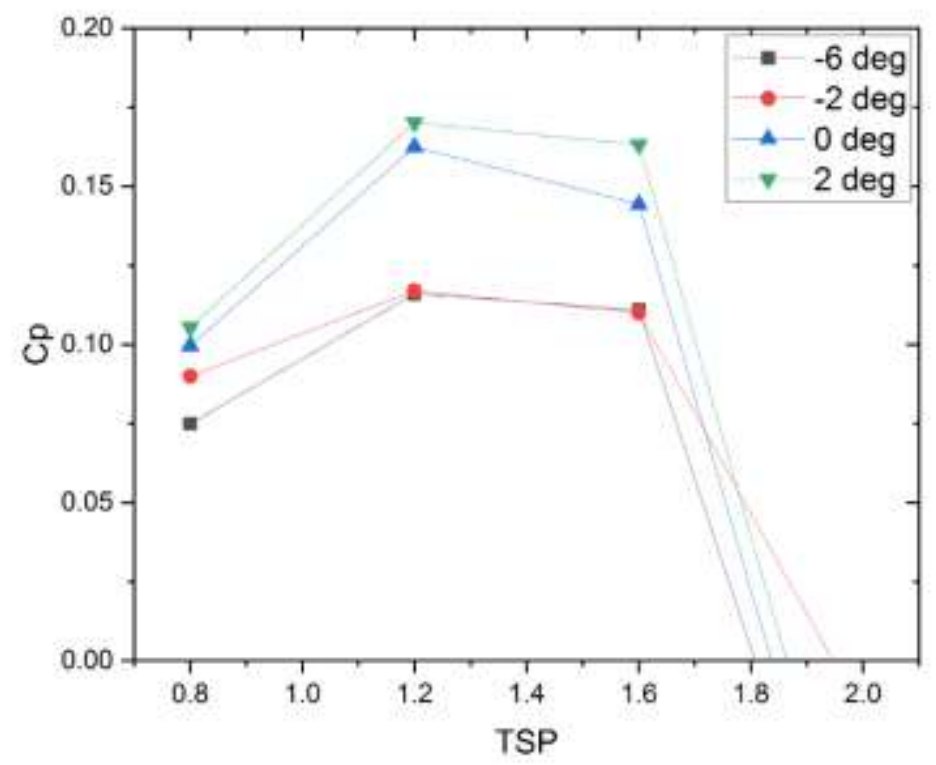

\section{Gambar 7. TSP versus CT Chart With Pitch Angle Variation}

Based on the results of this study, it can be concluded that the airfoil that has the best performance is the one that has an angle of $2^{\circ}$. Figure 8 shows the static pressure contour on the airfoil with an angle of $2^{\circ}$.

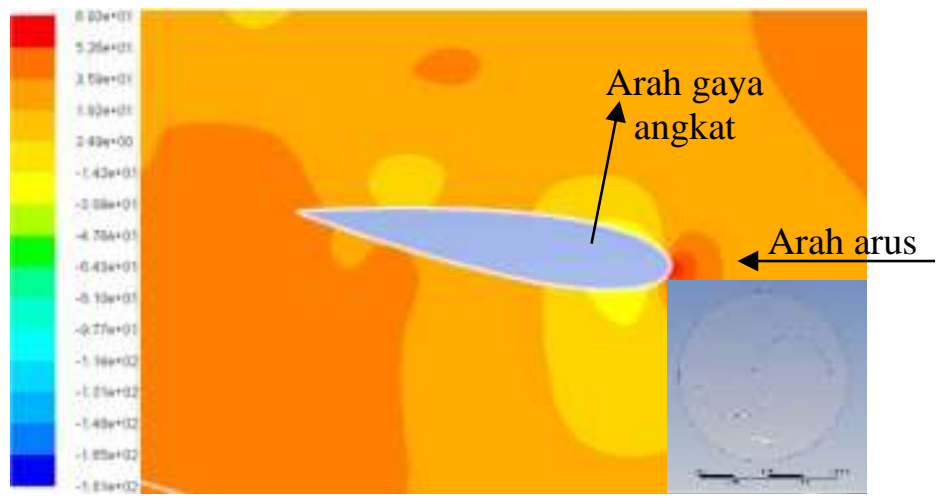

Figure 8. Static Pressure Contour at $2^{\circ}$ Angle

An angle of $2^{\circ}$ produces lift towards the front of the turbine. This direction corresponds to the movement of the turbine which rotates counterclockwise. In contrast to the angle below $2^{\circ}$ where the direction of the turbine is opposite to the turbine rotation.

\section{Conclussion}


Based on the results of the study, it can be concluded that the angle of $2^{\circ}$ has the best performance compared to the angle of $-6^{\circ},-2^{\circ}, 0^{\circ}$. This is because angle 2 provides a lifting force towards the front of the turbine in accordance with the direction of rotation of the turbine. As further research, it is recommended to increase the pitch angle variations so that a wider picture is obtained.

\section{References}

[1] Pranatal E, Beu MM. Analisa CFD Penggunaan Duct pada Turbin Kombinasi DarrieusSavonius. Jurnal IPTEK. 2018 May 31;22(1):63-70.

[2] Beu MM. Computational Fluid Dynamic for Performance Hydrofoil due to Angle of Attack. Journal of Earth and Marine Technology (JEMT). 2020 Sep 3;1(1):12-9.

[3] Abid M, Karimov K. S., Wajid H. A., Farooq F, Ahmed H, Khan O. H. (2014) "Experimental Study of Darrieus-Savonius Water Turbine with Deflector: Effect of Deflector on the Performace". Iranica Journal of Energi and Enviromental 6(1): 1-4, 2015

[4] Sahim Kaprawi, Ihtisan Kadafi, Santoso Dyos, Sipahutar Riman. (2014) "Experimental Study of Darrieus-Savonius Water Turbine with Deflector: Effect of Deflector on the Performance". International Journal of Rotating Machinery Volume 2014, Article ID 203108, February 20, 2014

[5] Kurniawan Iwan. (2014). Kajian Eksperimental dan Numerik Turbin air Helikal Gorlov untuk twist angle $60^{\circ}$ dan $120^{\circ}$. Jurnal Teknologi, V (1) 2014: 7-13 ISSN: 2087-5428.

[6] Yaakob Omar, Ahmed Yasser M, Ismail M Arif. (2012) Validation study for savonius vertical axis Marine Current turbine using CFD Simulation. In: The 6th Asia-Pacific Workshop on Marine Hydrodynamic-APHydro2012, September 3-4. 